\title{
The Risks and Strategies of High Leverage
}

\author{
Yuting Liu, Qingjun Meng, Yong Ma \\ Business School, Hohai University, Nanjing, China \\ Email: alwayswand@163.com
}

Received 1 August 2016; accepted 22 August 2016; published 25 August 2016

Copyright (C) 2016 by authors and Scientific Research Publishing Inc.

This work is licensed under the Creative Commons Attribution International License (CC BY). http://creativecommons.org/licenses/by/4.0/

(c) (i) Open Access

\begin{abstract}
Under the background of slow economic development speed, the state has issued a series of policies to realize destocking due to the serious real estate destocking in China. The problem about high leverage of real estate also emerges gradually due to the policies of reducing the proportion of down payment. The high leverage of real estate might bring about risks such as: building market bubble and increased risk in bank credit risk. However, there are a lot of difficulties to overcome to remove leverage. For example, the pressure over destocking is heavier and real estate bubble could be easily brought about. Only by positively adopting measures and conducting regulation positively, improving leverage structure of real estate market and boosting real estate market destocking, the financial risk can be prevented and controlled.
\end{abstract}

\section{Keywords}

\section{Real Estate, Remove Leverage, Estate Destocking, Financial Risk}

\section{Introduction}

In order to achieve the "real estate destocking" objective, the state has issued a series of favorable housing policy since 2015, such as adjusting the down payment ratio of housing provident fund loan, shortening the business tax exemption period. The overall easing policy has eased the pressure of real estate destocking to a certain extent, but it also detonates the real estate market and prices in some cities. According to the analysis of WIND information, the average house price in Shenzhen City was more than 40,000 yuan per square meter in December 2015 and the average price had an about $20 \%$ rise in the past 6 months to more than 50,000 yuan which is the highest price in China. In addition, Beijing, Shanghai, Guangzhou, these three first-tier cities were also seen a great degree of rise in prices. Rapid rises in average house prices were also seen in some quasi first-tier cities, such as Nanjing, Suzhou, where the average house prices had an over $21 \%$ increase in the past half year. Moreover, behind the high house prices and high growth, financial leverage plays an important role, as well as burying the hidden dangers. In order to control the risk of high leverage, many cities have issued control policies. 
For example, the document "on strengthening the personal housing loan risk control measures" issued by Shenzhen in 2016 is about housing loan risk. It's mainly to leverage and control the size of housing loan, so as to reduce the housing loan risk for banks. Shenzhen Municipal People's Government and Shanghai Municipal Government issued relevant documents, of which the main contents included enhancing the social security payment period and down payment for non-first-time buyers. Some experts pointed out that it would be another financial disaster if we did not interfere the high leverage in some local housing market. More attention should be paid to de-leveraging and risk reduction, and the lever can't be added to promote sales and de-stock. If the lever is added to de-stock, it will be contrary to the central spirit and will bring huge risks to the economy. In general, the lever in housing purchase of Chinese residents is still low, and the occurrence probability of financial risk is very low in strictly implementing the relevant credit policies. Starting from the goal of promoting housing consumption and preventing financial risks, the minimum down payment ratio should be appropriately increased in cities that have rapid growing housing price, such as Shenzhen and Suzhou. As for cities with stable prices and even falling prices, the minimum down payment ratio could be lowered down, especially for the families that buy the first house.

Based on China's current economic slowdown and the serious problem of property inventory, this paper aims at the risk analysis for the high leverage of Chinese property market, and gives the relevant countermeasures and suggestions for the de-leveraging. This paper firstly has a specific risk analysis to the Chinese high leverage, and puts forward that the soaring prices of large and middle cities are easy to cause the property market bubble and other risks. Then it analyzes that de-leveraging may cause bad situations, and finally gives relevant countermeasures and predicts the future development.

\section{Risk of Real Estate High Leverage}

\subsection{Prices Soared in Large and Medium Cities, Causing Housing Bubble}

Since 2015, along with the loose monetary policy and a series of real estate support policy, the house prices have been rising rapidly in China's real estate market, in particular, in first-tier cities such as Beijing and some hot second-tier cities like Nanjing and Hefei. According to WIND information, among the large and medium cities, there are 7 cities whose house prices had a more than $20 \%$ rise and an over $10 \%$ increase was seen in 14 cities between December in 2015 and June in 2016. On March 16, 2016, E-House real estate Institute published" the list of house price-income ratio in 35 large and medium cities". According to the list, Shenzhen has the highest house price-income ratio about 23.2 and if excluding the statistics of "affordable indemnificatory housing", the house price-income ratio is as high as 27.7 . House prices in large and medium cities have exceeded a reasonable range. Along with the Central Bank announced a lower down payment and the down payment support from the intermediary companies and small loan companies, people who can't afford a house are encouraged to buy house with loans and the number of investment property have been increasing which drive the rise of house prices. Rising prices promote the "buy up not buy down" (when a commodity price increases, people tend to predict that the price will continue to rise, so people is more inclined to buy it, which inspires their desire to buy more. And when a commodity price declines, people expect it to continue to fall, so they wait and do not buy it) group psychology of consumers and form a vicious circle and produce bubbles.

\subsection{Increasing Bank Credit Risk}

The As investors use "down payment loan" to buy houses is based on the expectation that house prices will be rising, and if the price rises to break through the rational limit and turn head down, investors especially those who invest later will lose everything and be in debt. Due to the loose monetary policy, such as lower down payment, risk-taking people whose income is unable to afford the down payment entered the real estate market. A large part of these people don't have steady income and they may be unable to repay the mortgage on time. Beyond that, products like "down payment loan" have high interest rate which increases the repayment pressure. Besides, the building market under such high leverage attracts a lot of real estate investors. By taking the stock market in last year for example, the stampede situation will be inevitably caused once in case of building market decline and more violations of contract will be also triggered. So, the result is very serious. No matter the direct bank loan or the down payment product released by real estate company, there are a lot of funds flowing out of the bank channel. As a result, the final risk will be brought to the bank from all directions. Eventually, bank becomes the taken for breaking the contract due to the house loan. After the bank takes back the house of the de- 
faulter, the housing price begins declining. As a result, a large number of default houses become the problem for the bank, so the bank risk will be increased [1].

\subsection{Unclear Capital Source of Asset Allocation Institutions}

As for the formation of high leverage of real estate, there is another important reason namely the emergence of financial leverages "external asset allocation" besides the policy reasons such as reduction in minimum down payment. As for the products including "down payment loan", by taking the purchase of house worth of 1 million Yuan with 20\% down payment for example, the purchase needs to pay 200 thousand Yuan firstly and borrow 800 thousand Yuan from the bank, thus forming 5 -fold leverage. Through the ways like down payment loan, the purchaser could borrow 100 thousand Yuan again in the part of down payment. Then he just needs to pay 100 thousand Yuan. Thus, 10-fold leverage will be brought. Besides, as for such way, besides the real estate intermediary works with developers, there is another way that is hard to supervise. Namely, through partnership with real estate developers and intermediaries is built through internet financial platforms and small-loan companies. Particularly, the source of funds provided by some network peer to peer platform (P2P). The threshold of the down payment loan of such P2P companies is very low [2]. By taking "YINGU PUHUI" for example, the loan applicant only needs to provide information such as ID certificate, work certification, income certificate and residential proof. The more provided credit certificates the higher the loan able amount. The monthly interest is $1.7 \%-1.8 \%$ or $2.3 \%-2.4 \%$. As for such external asset allocation, it is hard to grasp how many times of leverage is added specifically and how the proportion. However, fund source based on P2P platform cannot be monitored easily [3].

\section{The Resistance for Real Estate Destocking}

\subsection{Heavier Pressure over Real Estate Destocking}

Five tasks of economic work are defined in the Central Economic Working Conference in 2016: de-productivity, destocking, de-leverage, cost reducing and making up the short band. Real estate destocking is still the emphasis of real estate reform. Figure 1 shows that the sold area of commercial houses across the country in the first half of 2016 was increased by $27.9 \%$ on year-on-year basis. Though the initial success has been made by judging the data, the pressure over destocking in third and fourth-tier cities is actually still very heavy. In China, the policy imposes great influences on real estate market. At this time, if the "de-leverage" measure or policy is adopted, the shock will inevitably be brought to the real estate market. Even it is for de-leverage in first-tier city, certain influence will also be brought to purchasing psychology of other people. As a result, the threat is brought to the serious stock in these cities [4].

\subsection{Tight Policy May Promote the Disaster}

China's real estate bubble has formed. From the point of view of real estate development in other countries,
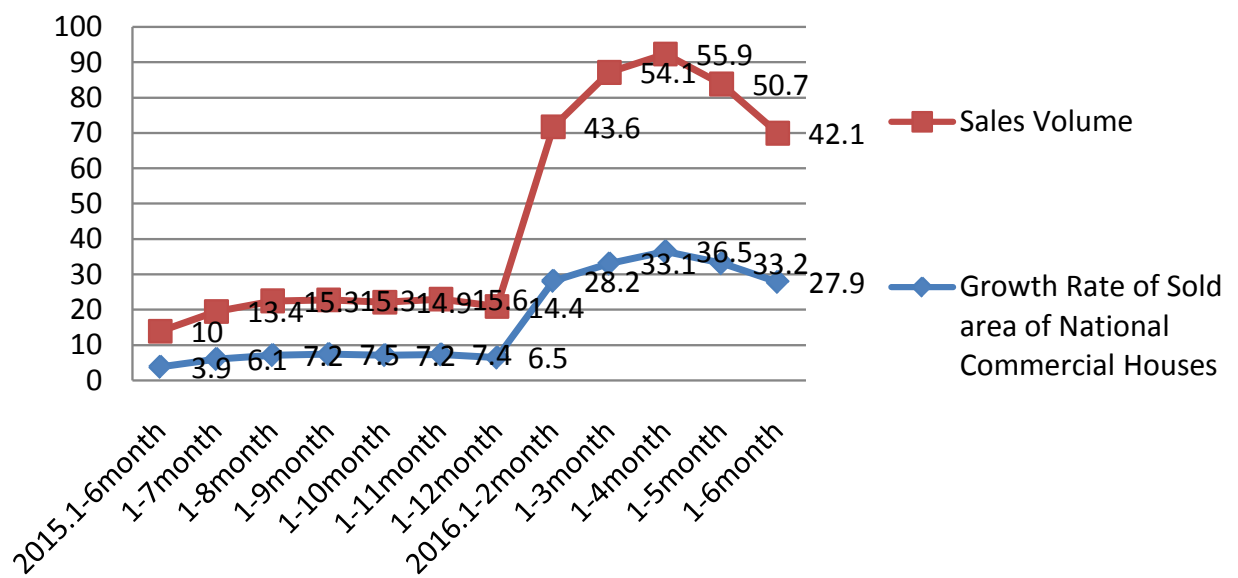

Figure 1. Growth rate of sold area of national commercial houses and of sales volume. 
overheated real estate economy and excessive house price eventually result in the bubble burst. The real estate bubble in Japan at the end of last century has many similarities to the real estate bubble in China today. And the last straw that broke the bubble was that when the Japanese government realized the serious bubble, it took too tight "de-leveraging" policy. In December 1989, the Bank of Japan had repeatedly raised the government's discount rate in a few months, pressed on commercial banks to stop lending to real estate companies, which had become the last straw to break the real estate bubble in Japan. Although the real estate bubble in China is not as serious as that of Japan, the de-leveraging policy would not be that strict, and it will also cause some impact on China's real estate bubble. It can be seen from the bubble disaster history of human that the balance between bubble and lever should be cautious. Sometimes tight policy will only promote the disaster, rather than restraining it. Perhaps the best way is to slowly digest the bubble by time [5].

\section{The Strategies of Remove Leverage}

\subsection{Control Policy Should Act According to Circumstances}

In view of the targets of excessive industrial capacity reduction and structure adjustment, as well as the challenges to China's economy brought by overseas economic shocks in 2016, there's no ground for blame for the government to add lever on real estate [2]. However, the housing prices in first-tier cities have increased rapidly since 2015, and the housing price in quasi first tier cities, such as Nanjing, Suzhou, also have repeatedly set new highs. For these cities, the main contradiction is in short supply, the housing price increases too quickly. In contrast, the property market in some third-tier cities and lower-tier cities, the inventory is still serious. Therefore, macro control policy should act according to circumstances. The de-leveraging process in the first tier cities and quasi first tier cities should be accelerated, so as to expand supply and control price bubble, while the third-tier cities and lower-tier cities should adopt a more lenient policy.

\subsection{Optimize the Lever Structure of the Real Estate Market}

China's real estate market is still in the stage that needs to take full advantage of the lever to accelerate destocking, the smooth implementation of de-leveraging cannot do without the stability of real estate market. Therefore, it's also important to promote sales with lever, and it's necessary to make clever use of finance to promote economic growth. Therefore, we should focus on optimizing the lever structure of the real estate market and coordinating the rhythm of de-leveraging and adding lever. Impact caused by de-leveraging should be slowed down through adding lever, so as to fit with China's overall economic development environment, enable the economic and society to optimize and upgrade in the balance development [6].

\subsection{Strictly Control External Asset Allocation Behavior and Strengthen Monitoring}

In new policy for real estate in Shenzhen in 2016, it is definitely indicated that it is necessary strengthen the real estate and financial risk prevention and control and start eliminating financial risk and adopt special measures and prohibit internet financial enterprises and small loan companies to be engaged in financial leverage asset allocation businesses such as: down payment loan, purchasing house through crowd funding and bridge loan by combining the risk elimination of down payment loan in the early stage. "Shanghai nine articles" also definitely point out that it is necessary to prohibit real estate development enterprises and intermediaries to be engaged in external asset allocation financial businesses such as: down payment loan, bridge loan, self-financing, selfguarantee and setting up capital pool. Many measures including reducing down payment and interest and increasing the limit of mortgage loan and down payment loan are "leverage-up" behaviors. Under current economic situation and background of real estate destocking, "de-leverage" cannot be made unanimously. Therefore, the incentive measure with small risk and perfect monitoring system could be properly retained. However, the "leverage-up" mode with larger risk and not easily monitored should be reduced or not allowed to better strengthen leverage monitoring.

\subsection{Guide Opinion and House Purchasers Analyze Real Estate Market Rationally}

The problem about real estate is an economic issue and political issue and further a livelihood issue, deeply affecting every citizen. However, the sheep-flock effect of Chinese real estate market is serious. Sheep-flock effect is a kind of group psychology. The sheep-flock behavior in financial market is a kind of special irrational 
behavior. It indicates the behavior that investors don't give considerations to their information for excessively relying on public opinion (namely the overwhelming concepts in market) [7]. To seize layout and attract attentions, the media including websites and newspaper have speculated over the real estate news in recent years. Such behaviors bring about great influences to extensive consumers to purchase houses and impede the macroscopic regulation order of real estate. Therefore, the media should firmly prohibit following the suit blindly and implementing commercial speculation. Besides, the practitioners also should strengthen self-cultivation, set good professional ethics of press to rationally guide people to set correct housing consumption idea.

\section{Conclusion}

The risks including high housing price and aggregated credit risk will be brought if the high real estate leverage is used to realize destocking. Therefore, it is an imperative to achieve de-leverage in real estate market especially in first-tier cities. However, the possible fluctuations also should be taken into account when realizing de-leverage. Therefore, it is not allowed to take methods such as prohibiting external asset allocation to realize regulation and control by adjusting the leverage structure. Besides, under the background of heavy pressure over destocking in the third-and fourth-tier cities, it is also necessary to realize real estate market de-leverage according to the local situation so as to mainly regulate the high leverage in the first-tier cities. It is expected that the de-leverage policy for the first-tier cities still has positive influences on regulation and control of housing price in the following $1-2$ years.

\section{References}

[1] Cai, Y.M. (2016) Real Estate High-Leverage and Destocking Is Not a Good Approach. Property Rights Guide, 4, 1112.

[2] Bi, F. (2016) Restoration and Deconstruction of "Down Payment Loan. Shanghai Enterprise, 4, 52-53.

[3] Ouyang, J. (2016) Cancel down Payment Loan. Can It Really Be Cancelled? People Daily, 18 March.

[4] Jiang, R.X. (2016) Monetary Issuance for Leverage up" Brings about Drastic Real Estate in 2016. Real Estate Guide, 4, 36-37.

[5] Zhang, S.F. (2005) Brief of Economic History of Real Estate Bubble in Japan. Macroeconomic Management, 6, 56-58.

[6] Mao, Z.H. (2016) De-Leverage and Financial Risk Control. China Finance, 10, 87-89.

[7] Liu, G.S. and Zhang, D.C. (2010) Provide Public Opinion Support for Sound Development of Real Estate Market. Zhumadian Daily, 30 December.

\section{Submit or recommend next manuscript to SCIRP and we will provide best service for you:}

Accepting pre-submission inquiries through Email, Facebook, LinkedIn, Twitter, etc.

A wide selection of journals (inclusive of 9 subjects, more than 200 journals)

Providing 24-hour high-quality service

User-friendly online submission system

Fair and swift peer-review system

Efficient typesetting and proofreading procedure

Display of the result of downloads and visits, as well as the number of cited articles

Maximum dissemination of your research work

Submit your manuscript at: http://papersubmission.scirp.org/ 